\title{
Penerapan Metode Weighted Product (WP) Dalam Keputusan Rekomendasi Pemilihan Manager Penjualan
}

\author{
Chairul Rizal ${ }^{1}$, Saidi Ramadan Siregar ${ }^{2, *}$ Supiyandi $^{3}$, Selly Armasari², Abdul Karim² \\ ${ }^{1}$ Prodi Sistem Komputer, Fakultas Sains dan Teknologi, Universitas Pembangunan Panca Budi, Medan, Indonesia \\ ${ }^{2}$ Program Studi Teknik Informatika, Universitas Budi Darma, Medan, Indonesia \\ ${ }^{3}$ Prodi Teknologi Informasi, Fakultas Sains dan Teknologi, Universitas Pembangunan Panca Budi, Medan, Indonesia \\ Email: ${ }^{1}$ napsterzal@gmail.com, ${ }^{2}$ saidiramadan89@gmail.com, ${ }^{3}$ supiyandi.mkom@gmail.com, ${ }^{4}$ selly.armasari@gmail.com, \\ 5abdkarim6@gmail.com \\ Penulis Email Korespondensi: saidiramadan89@gmail.com \\ Submitted: 20/12/2021; Accepted: 28/12/2021; Published: 31/12/2021
}

\begin{abstract}
Abstrak-Karyawan terbaik merupakan aset yang sangat penting bagi perusahaan, karena itu perusahaan penjualan membutuhkan sistem yang dapat memilih karyawan terbaik secara objektif dan optimal agar tepat dalam memilih karyawan terbaiknya yang akan berdampak pada kemajuan perusahaan. Untuk dapat memecahkan permasalahan penulis melakukan penelitian dengan menggunakan Sistem Pendukung Keputusan menggunakan metode Weighted Product (WP). Metode WP merupakan bagian dari Multiple Atribut Decision Making (MADM) yaitu didalam perhitungannya diperlukan proses normalisasi. Metode ini secara detail menghitung kepada bobot nilai dari setiap kriteria. Hasil akhir dari penelitian menunjukan alternatif ke 10 (A10) dengan Nilai Preferensi 0,1120 yang terpilih menjadi karyawan terbaik yang direkomendasikan dalam pemilihan manager penjualan.
\end{abstract}

Kata Kunci: Weighted Product; SPK; Karyawan Terbaik; Rekomendasi

\begin{abstract}
The best employees are very important assets for the company, because of that sales companies need a system that can choose the best employees objectively and optimally so that they are right in choosing the best employees who will have an impact on the progress of the company. To be able to solve the problem the author conducted research using a Decision Support System using the Weighted Product (WP) method. The WP method is part of the Multiple Attribute Decision Making (MADM), which requires a normalization process to be calculated. This method in detail calculates the weight of the value of each criterion. The final result of the research shows that the 10th alternative (A10) with a Preference Value of 0.1120 was chosen to be the best employee recommended in the selection of sales manager.
\end{abstract}

Keywords: Weighted Product; DSS; The Best Employee; Recommendation

\section{PENDAHULUAN}

Suatu perusahaan atau instansi selalu membutuhkan peranan sumber daya manusia (SDM) yang bekerja di dalamnya. Kualitas sumber daya manusia merupakan salah satu faktor yang diperlukan untuk meningkatkan produktifitas kinerja suatu perusahaan. Karyawan terbaik dan berkualitas yang dimiliki oleh perusahaan akan mampu di berikan suatu penghargaan berupa reward ataupun kenaikan jabatan untuk posisi tertentu pada perusahaan. Disamping itu karyawan terbaik juga merupakan suatu aset perusahaan yang akan membuat perusahaan dapat berkembang dengan pesat. Oleh karena perusahan membutuhkan karyawan yang memiliki kemampun yang handal serta berkualitas, salah satunya adalah dengan cara dengan melakukan pemilihan karyawan terbaik.

Dalam menentukan karyawan terbaik, perusahaan sangat perlu melakukan proses penilaian terhadap kinerja karyawan dengan menetapkan kriteria-kriteria yang dapat dikatagorikan sebagai karyawan terbaik seperti, prestasi karyawan, keahlian karyawan, kinerja karyawan, kedisiplinan, dan kerjasama tim saat bekerja. Pemilihan karyawan terbaik dilakukan secara periodik akan tetapi belum optimal dalam pelaksanaannya, Biasanya suatu perusahaan mendapati beberapa kendala dalam memutuskan karyawan yang akan diprioritaskan, dikarenakan banyaknya karyawan yang akan dinilai. Hal ini menjadi sebuah kekurangan untuk menentukan tepat atau tidaknya seseorang terpilih sebagai karyawan terbaik. Maka dari itu diperlukan sistem yang mampu menyelesaikan permasalahan tersebut yaitu sistem pendukung keputusan (SPK).

Sistem Pendukung Keputusan adalah suatu sistem informasi berbasis komputer yang digunakan untuk membantu dalam pengambilan keputusan dengan memanfaatkan data dan model tertentu untuk memecahkan suatu permasalahan yang tidak terstruktur [1]-[4]. Beberapa metode yang dapat digunakan dalam sistem pendukung keputusan yaitu WP (Weighted Product), SAW, TOPSIS, WASPAS, MOORA[5]-[9].

Saat ini banyak penelitian yang telah dilakukan terkait dengan pemilihan karyawan terbaik dengan menggunakan metode Weighted Product. EB Sambani pada tahun 2016 melakukan penelitian dengan judul Sistem Pendukung Keputusan Kenaikan Jabatan Karyawan Plaza Asia. Pada penelitiannya menghasilkan sistem yang dapat membantu dan mempermudah dalam menentukan kenaikan jabatan karyawan secara objektif[10]. Pada tahun yang sama H.R. Hatta melakukan penelitian terkait metode WP digunakan untuk memilih lokasi tanah pemakaman bagi umat muslim. Hasil yang dihasilkan dalam penelitiannya berupa lokasi lahan dengan ditampilkan visualisasi dari google maps[11]. Penelitian lain dilakukan pada tahun 2017 oleh M. Jalil berupa Sistem Pendukung Keputusan Pemberian Kredit Kepada 
BMT Mu'amalah Sejahtera Kediri. Output yang dihasilkan dapat membantu Pimpinan BMT Muamalah dalam menentukan calon debitur yang layak menerima kredit[12]. Penelitian berikutnya dilakukan oleh Syahfitri dengan judul Sistem Pendukung Keputusan Pemilihan Laptop Berbasis Web. Dibuat berupa Website dengan menerapkan metode WP. Hasil yang diberikan oleh sistem dalam penelitiannya berupa saran pembelian laptop dan tingkat akurasi keberhasilan sistem sebesar $100 \%[13]$.

Metode Weighted Product merupakan suatu metode dengan menggunakan perkalian untuk menghubungkan rating atribut, dimana rating setiap atribut harus dipangkatkan terlebih dahulu dengan bobot yang bersagkutan, proses ini sama halnya dengan proses normalisasi.

Berdasarkan pembahasan di atas, maka penulis tertarik untuk melakukan penelitian dengan menerapkan metode Weighted Product (WP) dalam memberikan keputusan rekomendasi calon manager penjualan. Hasil penelitian ini diharapkan mampu memberikan kontribusi kepada perusahaan dalam menentukan karyawan terbaik yang sifatnya lebih objektif dalam penilainnya.

\section{METODOLOGI PENELITIAN}

\subsection{Karyawan}

Karyawan adalah seorang pekerja yang berkerja untuk perusahaan yang menjadi aset utama perusahaan yang akan menjadi perencana dan pelaku aktif dari aktifitas organisasi dan akan mendapatkan kompensasi serta jaminan [14]. Karyawan terbaik yaitu karyawan yang memiliki kemampuan bekerja dengan baik dan optimal. Karyawan yang berkualitas juga memiliki kecerdasan dan rasa tanggung jawab yang tinggi untuk mendapatkan hasil terbaik dalam bekerja.

\subsection{Sistem Pendukung Keputusan}

Sistem Pendukung Keputusan (SPK), adalah sistem berbasis komputer yang fleksibel, interaktif dan dapat diadaptasi untuk mendukung suatu solusi dalam memecahkan masalah manajemen sfesifik yang tidak terstruktur. Dengan menggunakan data, memberikan antar muka pengguna yang relatif mudah dan dapat menggabungkan pemikiran dalam pengambilan keputusan [15]-[18].

\subsection{Metode Weighted Product (WP)}

Metode Weighted Product (WP) merupakan metode dalam pengambilan keputusan yang efisien dalam proses perhitungannya, metode ini banyak digunakan dalam menyelesaikan permasalahan dikarenakan waktu yang dibutuhkan lebih singkat dan efektif, dengan menggunakan perkalian antar nilai kriteria yang telah ditentukan, dimana nilai dari setiap kriteria harus dipangkatkan terlebih dahulu dengan bobot kriteria yang telah ditetpkan diawal. Proses ini sama dengan proses normalisasi [19]-[21]. Dalam proses perhitungannya, metode Weighted Product memiliki 3 langkah dalam penyelesaiannya, yaitu:

1. Membentuk matrik keputusan

2. Menghitung Vektor (Si)

3. Menghitung Preferensi (Vi)

Pada metode WP alternatif terbaik merupakan alternatif dengan nilai tertinggi.

\section{HASIL DAN PEMBAHASAN}

Pada penelitian ini penulis akan menganalisa beberapa alternatif yang dipilih sebagai karyawan terbaik sebagai rekomendasi calon manager penjualan pada perusahaan, untuk menghasilkan informasi yang efektif penulis mengumpulkan data-data yaitu data atribut, bobot kepentingan tiap atribut beserta data alternatif untuk penyelesaian dalam sistem pendukung keputusan yang dibuat meggunakan metode Weighted Product. Hasil akhir dari penelitian ini adalah sebuah alternatif yang memiliki nilai tertinggi yang akan terpilih menjadi karyawan terbaik dan dapat di rekomendasikan sebagai calon manager penjualan.

\subsection{Penetapan Kriteria dan Alternatif}

Berikut pada tabel 1, terdapat 5 (lima) kriteria yang digunakan dalam melakukan penilaian

Tabel 1. Kriteria yang digunakan

\begin{tabular}{lc}
\hline \multicolumn{1}{c}{ Kriteria } & Bobot \\
\hline Prestasi Karyawan $\left(\mathrm{C}_{1}\right)$ & $30 \%$ \\
Skill $\left(\mathrm{C}_{2}\right)$ & $20 \%$ \\
\hline
\end{tabular}




\begin{tabular}{ll}
\hline Kinerja Karyawan $\left(\mathrm{C}_{3}\right)$ & $15 \%$ \\
Masa Kerja $\left(\mathrm{C}_{4}\right)$ & $10 \%$ \\
Kedisiplinan $\left(\mathrm{C}_{5}\right)$ & $15 \%$ \\
Kerja Sama Tim $\left(\mathrm{C}_{6}\right)$ & $10 \%$ \\
\hline
\end{tabular}

Pada tabel 2 berikut terdapat 10 (sepuluh) orang karyawan yang menjadi kandidat (alternatif) yang akan dipilih sebagai karyawan terbaik. Berikut tabel dari rating kecocokan antara alternatif dan kriteria.

Tabel 2. Nilai Alternatif di Setiap Kriteria

\begin{tabular}{ccccccc}
\hline Alternatif & \multicolumn{5}{c}{ Kriteria/Tingkat } \\
& $\mathrm{C}_{1}$ & $\mathrm{C}_{2}$ & $\mathrm{C}_{3}$ & $\mathrm{C}_{4}$ & $\mathrm{C}_{5}$ & $\mathrm{C}_{6}$ \\
\hline Jefry $\left(\mathrm{A}_{1}\right)$ & Sangat Baik & Baik & Sangat baik & 6 Tahun & Cukup Baik & Baik \\
Imam $\left(\mathrm{A}_{2}\right)$ & Baik & Baik & Cukup Baik & 4 Tahun & Sangat baik & Sangat Baik \\
Naura $\left(\mathrm{A}_{3}\right)$ & Cukup Baik & Sangat Baik & Baik & 7 Tahun & Baik & Sangat Baik \\
Dion $\left(\mathrm{A}_{4}\right)$ & Cukup Baik & Baik & Baik & 6 Tahun & Sangat Baik & Baik \\
Siska $\left(\mathrm{A}_{5}\right)$ & Baik & Cukup Baik & Sangat Baik & 3 Tahun & Baik & Cukup Baik \\
Dinda $\left(\mathrm{A}_{6}\right)$ & Baik & Cukup Baik & Baik & 5 Tahun & Sangat Baik & Baik \\
Yoga $\left(\mathrm{A}_{7}\right)$ & Sangat Baik & Baik & Sangat Baik & 7 Tahun & Baik & Cukup Baik \\
Raisa $\left(\mathrm{A}_{8}\right)$ & Cukup Baik & Baik & Cukup Baik & 6 Tahun & Cukup Baik & Sangat Baik \\
Andre $\left(\mathrm{A}_{9}\right)$ & Baik & Cukup Baik & Baik & 8 Tahun & Baik & Baik \\
Nico $\left(\mathrm{A}_{10}\right)$ & Sangat Baik & Sangat Baik & Baik & 7 Tahun & Baik & Cukup Baik \\
\hline
\end{tabular}

Karena kriteria $\mathrm{C}_{1}, \mathrm{C}_{2}, \mathrm{C}_{3}, \mathrm{C}_{5}$ dan $\mathrm{C}_{6}$ merupakan kriteria linguistik, maka harus dibobotkan terlebih dahulu. Penentuan bobot dari setiap kriterianya yaitu:

Tabel 3. Pembobotan untuk C1,C2,C3,C5 dan C6

\begin{tabular}{cc}
\hline Keterangan & Nilai Bobot \\
\hline Sangat Baik & 5 \\
Baik & 4 \\
Cukup Baik & 3 \\
Kurang baik & 2 \\
Buruk & 1 \\
\hline
\end{tabular}

\subsection{Penerapan Metode WP}

Berikut di bawah ini merupakan tahapan dalam penerapan metode WP dalam pemilihan karyawan calon manager penjualan pada perusahaan.

Tahapan pertama, membentuk matrik keputusan yang di ambil dari tabel 1 yang terlebih dahulu nilai rating untuk kriteria C1, C2, C3, C5 dan C6 di bobotkan menggunakan tabel 3.

$\left|\begin{array}{llllll}5 & 4 & 5 & 6 & 3 & 4 \\ 4 & 4 & 3 & 4 & 5 & 5 \\ 3 & 5 & 4 & 7 & 4 & 5 \\ 3 & 4 & 4 & 6 & 5 & 4 \\ 4 & 3 & 5 & 3 & 4 & 3 \\ 4 & 3 & 4 & 5 & 5 & 4 \\ 5 & 4 & 5 & 7 & 4 & 3 \\ 3 & 4 & 3 & 6 & 3 & 5 \\ 4 & 3 & 4 & 8 & 4 & 4 \\ 5 & 5 & 4 & 7 & 4 & 3\end{array}\right|$

Tahapan kedua, menghitung nilai vektor dengan menggunakan persamaan berikut ini.

$$
S i=\prod_{j=1}^{n} x_{i j}{ }^{W_{j}}
$$

Untuk menghitung nilai vektor S yaitu dengan cara nilai dari setiap kriteria dipangkatkan dengan bobot kriteria yang bersangkutan lalu dikalikan seperti terlihat pada persamaan 1 di atas.

$S 1=\left(5^{0,3}\right)\left(4^{0,2}\right)\left(5^{0,15}\right)\left(6^{0,1}\right)\left(3^{0,15}\right)\left(4^{0,1}\right)=4,4110$ 


\section{Building of Informatics, Technology and Science (BITS)}

Volume 3, No 3, December 2021, Page 312-316

ISSN 2684-8910 (media cetak)

ISSN 2685-3310 (media online)

DOI 10.47065/bits.v3i3.1094

$S 2=\left(4^{0,3}\right)\left(4^{0,2}\right)\left(3^{0,15}\right)\left(4^{0,1}\right)\left(5^{0,15}\right)\left(5^{0,1}\right)=4,0508$

$S 3=\left(3^{0,3}\right)\left(5^{0,2}\right)\left(4^{0,15}\right)\left(7^{0,1}\right)\left(4^{0,15}\right)\left(5^{0,1}\right)=4,1491$

$S 4=\left(3^{0,3}\right)\left(4^{0,2}\right)\left(4^{0,15}\right)\left(6^{0,1}\right)\left(5^{0,15}\right)\left(4^{0,1}\right)=3,9511$

$S 5=\left(4^{0,3}\right)\left(3^{0,2}\right)\left(5^{0,15}\right)\left(3^{0,1}\right)\left(4^{0,15}\right)\left(3^{0,1}\right)=3,6865$

$S 6=\left(4^{0,3}\right)\left(3^{0,2}\right)\left(4^{0,15}\right)\left(5^{0,1}\right)\left(5^{0,15}\right)\left(4^{0,1}\right)=3,9930$

$S 7=\left(5^{0,3}\right)\left(4^{0,2}\right)\left(5^{0,15}\right)\left(7^{0,1}\right)\left(4^{0,15}\right)\left(3^{0,1}\right)=4,5444$

$S 8=\left(3^{0,3}\right)\left(4^{0,2}\right)\left(3^{0,15}\right)\left(6^{0,1}\right)\left(3^{0,15}\right)\left(5^{0,1}\right)=3,5842$

$S 9=\left(4^{0,3}\right)\left(3^{0,2}\right)\left(4^{0,15}\right)\left(8^{0,1}\right)\left(4^{0,15}\right)\left(4^{0,1}\right)=4,0474$

$S 10=\left(5^{0,3}\right)\left(5^{0,2}\right)\left(4^{0,15}\right)\left(7^{0,1}\right)\left(4^{0,15}\right)\left(3^{0,1}\right)=4,5954$

Tahapan terakhir, menghitung nilai preferensi (Vi) dengan menggunakan persamaan ke 2 seperti terlihat di bawah ini.

$$
V i=\frac{\prod_{j=1}^{n} X_{i j}{ }^{W_{j}}}{\prod_{j=1}^{n}\left(X_{i j}{ }^{*}\right)^{W_{j}}}(2)
$$

Untuk menghitung nilai preferensi $\left(V_{i}\right)$ yaitu dengan melakukan pembagian vektor $\mathrm{S}$, Hasil nilai vektor $\mathrm{S}$ dibagi dengan seluruh total nilai vektor S. Nilai $V_{i}$ terbesar adalah alternative yang terpilih. Berikut cara penyelesaiannya:

$$
\begin{aligned}
& V 1=\frac{4,4110}{41,0129}=0,1075 \\
& V 2=\frac{4,0508}{41,0129}=0,0988 \\
& V 3=\frac{4,1491}{41,0129}=0,1012 \\
& V 4=\frac{3,9511}{41,0129}=0,0963 \\
& V 5=\frac{3,6865}{41,0129}=0,0899 \\
& V 6=\frac{3,9930}{41,0129}=0,0973 \\
& V 7=\frac{4,5444}{41,0129}=0,1108 \\
& V 8=\frac{3,5842}{41,0129}=0,0874 \\
& V 9=\frac{4,0474}{41,0129}=0,0987 \\
& V 10=\frac{4,5954}{41,0129}=0,1120
\end{aligned}
$$

Dari semua proses penyelesaian yang dilakukan didapatkan hasil akhir:

Tabel 4. Hasil Perhitungan Akhir

\begin{tabular}{cccc}
\hline Alternatif & Nama & Vi & Peringkat \\
\hline A1 & Jefry & 0,1075 & 3 \\
A2 & Imam & 0,0988 & 5 \\
A3 & Naura & 0,1012 & 4 \\
A4 & Dion & 0,0963 & 8 \\
A5 & Siska & 0,0899 & 9 \\
A6 & Dinda & 0,0973 & 7 \\
A7 & Yoga & 0,1108 & 2 \\
A8 & Raisa & 0,0874 & 10 \\
\hline
\end{tabular}




\begin{tabular}{cccc}
\hline Alternatif & Nama & Vi & Peringkat \\
\hline A9 & Andre & 0.0987 & 6 \\
A10 & Nico & 0,1120 & 1 \\
\hline
\end{tabular}

Dari hasil perangkingan pada tabel di atas dapat terlihat bahwa nilai preferensi terbesar terdapat pada alternatif A10 dengan nilai preferensi 0,1120, jadi dapat disimpulkan bahwa karyawan yang bernama Nico yang layak untuk menjadi Karyawan yang direkomendasikan sebagai calon manager penjualan pada perusahaan.

\section{KESIMPULAN}

Dari penelitian dan pembahasan yang telah di uraikan di atas dapat disimpulkan bahwa sistem pendukung keputusan dengan menggunakan metode Weighted Product ini dapat diterapkan dengan seefektif mungkin dan mampu memberikan hasil berupa peringkat dari karyawan terbaik. Karyawan yang memiliki peringkat terbaik merupakan dengan nilai yang tertinggi yang nantinya dapat di rekomendasikan sebagai calon manager penjualan di perusahaan. Hasil penelitian diharapkan dapat memberi keputusan yang lebih objektif dalam pemberian rekomendasi calon manager penjualan perusahaan.

\section{REFERENCES}

[1] M. Anas, D. Azizi, I. Ukkas, and S. Qomariah, "SISTEM PENDUKUNG KEPUTUSAN PENENTUAN INTERNAL PART ORDER MENGGUNAKAN METODE SIMPLE MULTI ATTRIBUTE RATING TECHTIQUE ( SMART ) PADA PT . TRINITY AUTO,” pp. 2-7, 2007.

[2] J. E. and L. T. P. Turban, A. Efraim, Decision Support System and Intelegence Systems, 7th ed. Jogjakarta: Penerbit Andi, 2015.

[3] Kusrini, Konsep dan Aplikasi Sistem Pendukung Keputusan. 2007.

[4] T. Limbong et al., Sistem Pendukung Keputusan: Metode \& Implementasi. Medan: Yayasan Kita Menulis, 2020.

[5] N. K. Daulay, B. Intan, and M. Irvai, "Comparison of the WASPAS and MOORA Methods in Providing Single Tuition Scholarships," IJICS (International J. Informatics Comput. Sci., vol. 5, no. 1, pp. 84-94, 2021.

[6] N. K. Daulay, "Penerapan Metode Waspas Untuk Efektifitas Pengambilan Keputusan Pemutusan Hubungan Kerja," J. Sist. Komput. dan Inform., vol. 2, no. 2, pp. 196-201, 2021.

[7] Mesran, E. P. Sumantri, Supriyanto, S. H. Sahir, and N. K. Daulay, "Implementation of Technique for Order Preference by Similarity to Ideal Solution (TOPSIS) in Recommendations for New Position in Companies," Int. J. Inf. Syst. Technol., vol. 4 no. 2, pp. 661-669, 2021.

[8] I. J. T. Situmeang, S. Hummairoh, S. M. Harahap, and Mesran, "Application of SAW ( Simple Additive Weighting ) for the Selection of Campus Ambassadors," IJICS (International J. Informatics Comput. Sci., vol. 5, no. 1, pp. 21-28, 2021.

[9] R. Y. Simanullang, Melisa, and Mesran, "Sistem Pendukung Keputusan Penerima Bantuan Covid-19 Menggunakan Metode Simple Additive Weighting (SAW)," TIN Terap. Inform. Nusant., vol. 1, no. 9, pp. 2-9, 2021.

[10] E. B. Sambani, Y. H. Agustin, and R. Marlina, "Sistem Pendukung keputusan Kenaikan Jabatan Karyawan Plaza Asia Dengan Menggunakan Metode Weighted Product," CSRID (Computer Sci. Res. Its Dev. Journal), vol. 8, no. 2, p. $121,2016$.

[11] H. R. Hatta, M. Rizaldi, and D. M. Khairina, "Penerapan Penerapan Metode Weighted Product Untuk Pemilihan Lokasi Lahan Baru Pemakaman Muslim Dengan Visualisasi Google Maps,” vol. 02, no. 03, pp. 85-94, 2016.

[12] M. Muchtar, "Spk pemberian kredit menggunakan metode wp (weighted product) pada bmt mu'amalah sejahtera kendari," no. July, 2019.

[13] N. A. Syafitri and A. P. Dewi, "Penerapan Metode Weighted Product Dalam Sistem Pendukung Keputusan Pemilihan Laptop Berbasis Web," semanTIK, vol. 2, no. 1, pp. 169-176, 2016.

[14] S. Mallu, "Sistem pendukung keputusan penentuan karyawan kontrak menjadi karyawan tetap menggunakan metode topsis," $J$. Ilm. Teknol. dan Inf. Terap., vol. 1, no. 2, pp. 36-42, 2015.

[15] Abdul Khadir, "Sistem Pendukung Keputusan," Sist. Pendukung Keputusan, pp. 5-22, 2014.

[16] D. Nofriansyah, Multi Criteria Decision Making. Yogyakarta: Deepublish, 2017.

[17] D. Nofriansyah, Konsep Data Mining Vs Sistem Pendukung Keputusan. 2015.

[18] S. Kusumadewi, S. Hartati, A. Harjoko, and Retantyo Wardoyo, Fuzzy Multi-Attribute Decision Making (FUZZY MADM). 2006.

[19] A. Hafiz and M. Ma'mur, "Sistem Pendukung Keputusan Pemilihan Karyawan Terbaik Dengan Pendekatan Weighted Product," Cendikia, vol. 15, no. 2, pp. 23-28, 2018.

[20] Solikhun, "Perbandingan Metode Weighted Product dan Weighted Sum Model dalam Pemilihan Perguruan Swasta Terbaik Jurusan Komputer," Klik - Kumpul. J. Ilmu Komput., vol. 4, no. 1, p. 70, 2017.

[21] A. Setyawan, F. Y. Arini, and I. Akhlis, "Comparative Analysis of Simple Additive Weighting Method and Weighted Product Method to New Employee Recruitment Decision Support System (DSS) at PT. Warta Media Nusantara," Sci. J. Informatics, vol. 4, no. 1, pp. 34-42, 2017. 